\title{
Pendidikan Islam \\ Berwawasan Multikultural
}

\author{
Masnur Alam, Daflizar \\ Institut Agama Islam Negeri (IAIN) Kerinci \\ masnur.alam@yahoo.co.id, daflizar@gmail.com
}

\begin{abstract}
Which is prone to cause conflict, thus State Islamic Institute of Kerincias one of the stateuniversities feels obliged to include multicultural courses into its curriculum. The purpose of this study was to know the implementation of "Islamic Education with Multicultural Insights" at the State Islamic Institute ofKerinci. This research was a field research study, with the qualitative type. The main instruments were observation, indepth interviews, and documentation. The findings of the study are: That the State Islamic Institute ofKerincihas implemented Islamic education with multicultural insights through the lecture process, beginning with designing a syllabus that contains the strengthening of the theory, that God has created cultural diversity which is sunnatullah, rabmat, assets, strength, unifying tool that must be appreciated and thankful for, and that cultural diversity, peace and harmony have received a positive response from the students that they canapply in their daily life and even they are be able to be a massive pioneer in creating peace and harmony in society.
\end{abstract}

Key terms: Islamic Education With Multicultural Insigths, Peace, Harmony

Abstrak: Penelitian ini dilatar belakangi oleh karena masyarakat Kerinci merupakan masyarakat yang majemuk terdiri dari bermacam etnis, suku dan budaya, yang rawan menimbulkan konflik, maka IAIN Kerinci merupakan salah satu Perguruan Tinggi Negeri merasa berkewajiban untuk memasukkan mata kuliah multikultural ke dalam kurikulum. Adapun tujuan penelitian ini untuk mengetahui "Pendidikan Islam Berwawasan Multikultural: Studi Implementasi di Institut Agama Islam Negeri (IAIN) Kerinci”. Penelitian ini merupakan penelitian field research, dengan jenis kualitatif. Instrumen utamanya adalah observasi, wawancara mendalam, serta studi dokumentasi. Temuan penelitian adalah: Bahwa IAIN Kerinci telah mengimplementasi pendidikan Islam berwawasan multikultural melalui proses perkuliahan, diawali dengan membuat Satuan Acara Perkuliahan (SAP) yang berisi penguatan teori, bahwa Allah telah menciptakan keragaman budaya yang merupakan sunnatullah, rahmat, asset, kekuatan, perekat yang harus dihargai dan disyukuri, serta keragaman budaya, kedamaian dan harmoni, ini mendapat 
respons positif dari mahasiswa, mereka dapat membiasakan, menerapkan bahkan mampu menjadi pelopor secara masif dalam menciptakan kedamaian dan kehermonisan dalam masyarakat.

Kata Kunci: Pendidikan Islam Multikultural, Kedamaian, Keharmonisan

\section{Pendahuluan}

Hampir 200 bahasa dan lebih dari 13,500 pulau, serta keragaman Masyarakat Indonesia terkenal sebagai masyarakat yang multikultural, sebagaimana disebut dalam Indosiar Tv dalam acara Mata Indonesia tanggal 19 Juli 2015 yang terdiri dari lebih kurang 1.128 suku bangsa, 350 kelompok etnis, menggunakan agama. Oleh karena itu masyarakat Indonesia dapat disebut sebagai masyarakat yang multikultural terbesar di dunia.. Dengan kondisi masyarakat yang multikultural tersebut, maka Indonesia merupakan negara yang sangat rawan terjadinya konflik, baik dalam bentuk konflik horizontal dan vertikal, baik konflik darat maupun maritin. Terjadi dari tingkatan akar rumput rakyat biasa, sampai ke tingkatan elit. Dilakukan baik sipil maupun aparat meliter.

Salah satu upaya yang dapat dilakukan melalui kebijakan pada lembaga pendidikan, yaitu dengan mengimplementasikan Pendidikan Islam yang berwawasan multikultural. Namun pemasalahannya, bila diamati pendidikan Islam yang diberikan di perguruan tinggi di Indonesia pada umumnya belum banyak mengimplementasikan pendidikan Islam yang berwawasan multikultural, padahal sudah terjadi perubahan atau perkembangan yang cukup deras pada struktur masyarakat, terutama segi kultural dari kelompok homogen ke hetrogen, dari masyarakat statis ke dinamis. Dalam menghadapi perubahan sosial yang sangat deras tersebut, maka tidak ada alasan lagi untuk tidak menerima perbedaan apapun di negeri ini, termasuk diversitas budaya, heterogenitas masyarakat, dan keragaman suku bangsa.

Berdasarkan identifikasi masalah tersebut, maka Institut Agama Islam Negeri (IAIN) Kerinci, telah memasukkan kurikulum "pendidikan multikultural" diantaranya pada Jurusan Bimbingan Konseling Pendidikan Islam (BKPI), pada sementer genap, telah mencoba merespons terhadap isu-isu 
kontemporer melalui pendidikan Islam berwawasan multikultural dalam bentuk "pendidikan hadhari" (pendidikan berperadaban dan berkemajuan) menjadikan ilmu ke-Islam-an sebagai rabmatan lil alamin tanpa membedakan golongan, ras, suku, bangsa maupun agama, yang sesuai dengan kebutuhan masyarakat. Hal ini sesuai dengan apa yang diungkapkan Mastuki ${ }^{1}$ bahwa PTAI merupakan bagian dari institusi sosial (sosial institutions) yang saling memengaruhi satu sama lain, merupakan bagian komunitas dunia yang terus bergerak. Globalisasi berikut dampak iringannya (naturant effect) sedikit banyak mengguncang pertahanan PTAI. Pada aras inilah perombakan kurikulum menemukan titik terangnya, perlu direvisi atau diperbaiki.

Maka problema multikultural perlu dikelola secara positif yang diintegrasi dengan pendidikan Islam, diyakini mampu memberi alternatif dengan mencari strategi khusus untuk menemukan solusi atas persoalan multikulturalisme tersebut. Jurusan Konseling Pendidikan Islam (BKPI) beserta dengan para dosen pengasuh telah berupaya mengambil kebijakan dan upaya reformatif dan rekonstruktif serta memiliki kemampuan responsif (responsive cafabaliti) terhadap fenomina sosial yang berkembang dewasa ini, selalu meningkatkan kemampuannya dalam menghadapi perubahan masyarakat yang sangat cepat, serta dapat memberi kontribusi yang konstruktif positif serta merespons kondisi masyarakat yang multikultural.

Ini diakui sebagai tantangan (challenger), namun dalam hal ini sekaligus dapat dijadikan sebagai peluang dan kesempatan (opportunities) untuk menyadari atas segala kelemahan yang bisa dimanfaatkan dalam mengumpulkan kekuatan dengan melakukan perubahan agar tetap eksis dan diminati masyarakat secara luas. Harapannya, pendidikan Islam berwawasan multikultural dapat menanam simpati, apresiasi, dan empati terhadap penganut budaya yang berbeda. Lebih jauh lagi penganut budaya dan agama yang berbeda dapat belajar untuk melawan ketidaktoleranan, diskriminasi, dan hegemoni budaya di tengah kultur monolitik dan uniformitas global.

\footnotetext{
1 Mastuki, Kualitas Lulusan Perguruan Tinggi dan Akseptabilitas Stakeholders (Pemikiran untuk Perombakan Kurikulum di PTAI), Disamapaikan pada Seminar Reorientasi Kurikulum dan Kerja sama Lembaga STAIN Kerinci, Rabu, 8 Januari 2014.
} 
Pendidikan Islam yang dimaksud adalah pendidikan agama Islam yang berwawasan multikultural dengan model pendidikan mengedepankan pluralisme, toleransi, keadilan, saling menghargai perbedaan (agree in disagreement), dapat hidup saling berdampingan satu dengan yang lain (to live together), dapat menciptakan kesejukan dan kenyamanan (antihegemoni dan antidominasi). Dengan mensejajarkan persaudaraan antar sesama agama (ukhuwah Islamiyah, persaudaraan antar sesama bangsa (ukhwah wathaniyah) dan persaudaraan antar sesama manusia (ukhwah basyariyah), serta globalisasi pendidikan Islam yang arif dan bijaksana. Jadi globalisasi bisa menjelma menjadi peluang (apportunity), bisa pula menjadi tantangan (threat). Maka dalam menghadapi hal ini, pendidikan Islam berupaya menarik-alur arus global, yang sesuai ditarik atau diambil dan dicerna, sementara yang tidak sesuai, diulur, dilepas atau ditinggalkan.

Fenomena tersebut di atas, mendeskripsikan kondisi pendidikan Islam yang dilaksanakan selama ini belum dapat merespons kondisi masyarakat yang selalu berubah atau yang sangat dinamis terutama isu-isu terkini yang dihadapi pendidikan Islam, yaitu pendidikan multikultural (keanekaragaman kultur). Hal ini sangat mendesak untuk dikaji, dicari solusi dan direspons dengan positif, terutama melalui muatan kurikulum pendidikan Islam berwawasan atau bermuatan multikultural. Maka penelitian ini berupaya mengungkapkan secara gamblang terhadap "Pendidikan Islam Berwawasan Multikultural: Studi Implementasi di Institut Agama Islam Negeri (IAIN) Kerinci”.

\section{Metode Penelitian}

Jenis penelitian ini adalah field risearch berbentuk penelitian kualitatif yang menghasilkan data deskriptif, yang berhubungan dengan kebijakan serta hasil dari implementasi kebijakan tersebut. Dengan landasan filosofinya adalah fenomenalogi, data tersebut dianalisis dan diinterpretasikan. Sesuai dengan landasan filosofis yang menafasinya, penelitian ini bersumber pada data faktual yang terjadi sebagaimana apa adanya. Sedangkan lokasi penelitian adalah Institut Agama Islam Negeri (IAIN) Kerinci, tepatnya di Jurusan Bimbingan Konseling Pendidikan Islam (BKPI), salah satu jurusan yang terdapat pada IAIN Kerinci. Kampus ini terletak di Jalan Kapten Muradi Kecamatan Pesisir Bukit Kota Sungai Penuh. Merupakan kampus yang ASRI (Aman, Sejuk, Rindang, dan Indah) serta nyaman untuk proses pendidikan. 
Informan pada penelitian ini adalah dosen yang mengampu mata kuliah Pendidikan Multikultural pada jurusan Bimbingan Konseling Pendidikan Islam (BKPI) sebagai informan awal. Jika ini tidak merasa lengkap, maka dikembangkan jumlahnya sampai peneliti mendapat informasi yang cukup. Disamping itu juga meneliti serta menganalisis kurikulum mata kuliah Multikultural dalam bentuk dokumen. Selanjutnya pengumpulan data dilakukan melalui wawancara mendalam dengan informan, disamping itu juga dengan melakukan observasi partisipatoris secara berulang-ulang di lokasi penelitian. Peneliti juga menganalisis dokumen yang berhubungan dengan kurikulum dan Rencana Pembelajaran atau Satuan Acara Perkuliahan (SAP).

Analisis yang digunakan pada penelitian ini adalah model analisis data mengalir (flow model), analisis data telah dimulai sejak merumuskan dan menjelaskan masalah sebelum terjun ke lapangan sampai pada waktu pengumpulan data, pengolahan analisa data, sampai penulisan laporan akhir penelitian, dilakukan secara terpadu.

\section{Tinjauan Kepustakaan}

Istilah multikultur atau multikultural awalnya merujuk kepada istilah multiculturalism yang dalam konteks negara Kanada (di mana istilah ini pertama kali dipopulerkan tahun 1950-an) digunakan sebagai sinonim dari pluralism (kemajemukan) dan diversity (keanekaragaman). Majemuk yang dimaksud di sini adalah kemajemukan yang bersifat horizontal, yakni (adanya berbagai macam suku, bangsa, etnis, bahasa, agama, adat-istiadat, dan lain-lain), maupun vertikal, yakni (adanya berbagai kelompok masyarakat yang dapat dipilah-pilah atas dasar mode of production, yang bermuara pada perbedaan daya adaptasinya. Sedangkan keanekaragaman adalah keberagaman dan saling menerima perbedaan bahkan saling melengkapi, saling menghargai. Secara sederhana multi berarti banyak, ragam, atau aneka, kultul berarti kebudayaan. Multikultural berarti banyak, keragaman, atau aneka kebudayaan, yang harus dihargai dan dihormati serta dijunjung tinggi. 
Pendidikan multikultural menurut Amir Rusdi² dimaknai sebagai usahausaha edukatif yang diarahkan untuk dapat menanamkan nilai-nilai kebersamaan kepada peserta didk dalam lingkungan yang berbeda baik ras, etnik, agama, budaya, nilai-nilai, dan edeologi sehingga memiliki kemampuan untuk dapat hidup bersama dalam perbedaan dan memiliki kesadaran untuk hidup berdampingan secara damai. Menurut Azyumardi Azra ${ }^{3}$ pendidikan multikultural sebagai pengganti dari pendidikan interkultural, diharapkan dapat menumbuhkan sikap peduli dan mau mengerti atau adanya politik pengakuan terhadap kebudayaan kelompok manusia seperti; toleransi, perbedaan etnokultural dan agama, diskriminasi, HAM, demokrasi dan pluralitas, kemanusiaan universal serta subjek-subjek lain yang relevan.

Pada buku lain Azyumardi Azra ${ }^{4}$ mengatakan pula multikulturalisme kesediaan menerima kelompok lain secara sama sebagai kesatuan, tanpa mempedulikan perbedaan budaya, etnik, jender, bahasa, ataupun agama. Terhadap semua perbedaan sebagai entitas dalam masyarakat yang harus diterima, dihargai, dilindungi serta dijamin eksistensinya. Begitu pula Dede Rosyada $^{5}$ menjelaskan bahwa pendidikan multikultural biasa diartikan sebagai pendidikan keragaman budaya dalam masyarakat, dan terkadang juga diartikan sebagai pendidikan untuk membina sikap mahasiswa dan siswa agar menghargai keragaman budaya masyarakat. Sedangkan Zakiuddin Baidhawi ${ }^{6}$ menyimpulkan ada tujuh asumsi paradigmatik pendidikan Islam berbasis multikultural, yaitu mendidik mahasiswa untuk: 1) belajar hidup dalam perbedaan; 2) membangun saling percaya; 3) memelihara saling pengertian; 4) menjunjung sikap saling menghargai; 5) terbuka dalam berpikir; 6) apresiasi dan interdependensi; 7) resolusi konflik dan rekonsiliasi tanpa kekerasan.

${ }^{2}$ Amir Rusdi, "Perspektif Islam tentang Keberagaman dan Penyikapannya dalam Konteks Pengembangan Kurikulum PAI” dalam Conciencia, Vol.1 No.2, 2007.

${ }^{3}$ Azyumardi Azra, Pendidikan Agama Multikultural, (Jakarta: UIN Syarif Hidayatullah, 2004), h. 89.

${ }^{4}$ Azyumardi Azra, Merawat Kemajemukan Merawat Indonesia, (Yokyakarta: Institute Pluralism and Multikultarism Studies (Impulse) dan Kanisius, 2007), h. 13.

${ }^{5}$ Dede Rosyada, "Pendidikan Multikultural melalui Pendidikan Agama Islam", dalam Didaktika Islamika: Jurnal Kependidikan, Keislaman dan Kebudayaan, Vol. VI, Nomor 1, Januari 2005, h. 21-22.

${ }^{6}$ Zakiyuddin Baidhawi, "Multicultural Education for Stregthening Civil V alues in Pesantren", 2008, h. $78-84$. 
Sedangkan muatan nilai-nilai multikultural dalam pendidikan Islam menurut Abd. Rachman Assegaf ${ }^{7}$ dapat disimpulkan: Kategori nilai-nilai utama terdiri dari: Taubid, mengesakan Tuhan. Ummah, hidup bersama. Rahmah, kasih sayang. Al-musawah, taqwa (egalitarianism). Kategori Penerapan: Ta'aruf, Ihsan, saling mengenal dan berbuat baik, Tafahum, saling memahami. Takrim, saling menghormati. Fastabiqul khairat, berlomba dalam kebaikan. Amanah, saling memercaya. Husnuəhan, berpikir positif. Tasamuh, toleransi.'Afw, maghfirah, pemberian/permohonan ampunan. Sulh, perdamaian atau rekonsiliasi. Islab atau resolusi konflik. Kategori Tujuan: Silah, salam atau perdamaian. Layyin, lemah lembut atau budaya anti kekerasan. 'Adl atau keadilan dan jujur.

Basis multikultural adalah pluralisme, yang menjadi fakta sosial yang tidak bisa diingkari. Pluralisme harus dipelihara dan dikelola dengan baik guna memperkuat struktur politik dan mengukuhkan sistem demokrasi bangsa Indonesia. Pluralisme agama pada intinya adalah toleransi agama (religious tolerance). Menurut Nurcholis $\mathrm{Madjid}^{8}$, komunitas agama harus mampu menerima kenyataan pluralitas kehidupan modern serta tak bisa ditawar-tawar dan suatu keharusan. Namun isu pluralisme dan multikulturalisme tersebut selama hampir masa penguasa Orde Baru nyaris tidak tersintuh, lembaga pendidikan tidak pernah dipercaya untuk mentransformasi serta menginternalisasikannya kepada anak didiknya. Baru kemudian menurut Imam Tholhkhoh dan Ahmad Barizi ${ }^{9}$ Undang-undang SISDIKNAS 2003 membuat suatu ancangan ke arah pendidikan multikulturalisme, karena menyadari memang negara ini diwarnai multiagama, multietnik, dan multibudaya.

Dalam kasus Islam, pluralisme kehidupan dan toleransi jelas memiliki legitimasi keagamaan. Pluralisme menurut Budhy Munawar Rachman ${ }^{10}$ harus

7 Abd. Rachman Assegaf, Filsafat Pendidikan Islam, Paradigma Baru Pendidikan Hadhari Berbasis Integratif-Interkonetif, (Jakarta: Raja Grafindo Persada, 2011), h.313.

${ }^{8}$ Nurcholis Madjid, 'Islamic Roots of Modern Pluralis; Indonesien Experiences" dalam Jurnal Studia Islamica, (Jakarta: IAIN Syarif Hidayatullah, 1994), h. 55.

'Imam Tholhkhah dan Ahmad Barizi, Membuka Jendela Pendidikan Mengurai Akal Tradisi dan Integrasi Keilmuan Pendidikan Islam, (Jakarta: Raja Grafindo Persada, 2004), h.179.

${ }^{10}$ Budhy Munawar Rachman, Islam Pluralis, Wacara Kesetaraan Kaum Beriman Paramadina, (Jakarta: Paramadina, 2001), h. 31. 
dipahami sebagai "pertalian sejati kebhinekaan dalam ikatan-ikatan keadaban". Bahkan pluralisme juga merupakan suatu keharusan bagi keselamatan umat manusia, antara lain melalui mekanisme pengawasan dan pengimbangan yang dihasilkannya. Adapun yang menjadi landasan adalah piagam Madinah merupakan benih yang kuat untuk dapat ditumbuhkan menjadi sistem kehidupan pluralistik bagi masyarakat kosmopolit. Landasan lain yang turut memperkokoh kehidupan pluralistik adalah ajaran Islam yang menganjurkan untuk berpegang pada kesamaan pandangan dengan komunitas agama yang lain dalam mewujudkan kerukunan dan kedamaian serta menjauhi konflik dan kekerasan.

Di samping itu tipologi sikap keberagamaan adalah inklusivisme, yang berpandangan bahwa di luar agama yang dipeluknya juga terdapat kebenaran, meskipun tidak seutuh atau sesempurna agama yang dianutnya. Begitu juga dalam hak kebudayaan. Pengakuan adanya kebenaran yang dianut memang harus dipertahankan. Akan tetapi menurut Komarudin Hidayah ${ }^{11}$ pengakuan itu harus memberi tempat pula pada agama lain sebagai sebuah kebenaran yang diakui secara mutlak oleh para pemeluknya. Begitu pula Nurcholish Madjid ${ }^{12}$, mengemukakan sikap inklusif adalah memandang bahwa agama-agama lain sebagai bentuk implisit agama Islam yang dianutnya. Dia masih tetap meyakini bahwa agamanya paling baik dan benar, namun dalam waktu yang sama, mereka memiliki sikap toleran dan bersahabat dengan pemeluk agama lain. Inklusivitas beragama dan budaya memang sangat diperlukan dalam memelihara perdamaian.

Adapun pendidikan Islam berwawasan multikultural, yang mengakui kemajmukan dapat dilihat (Q.S. Hud [11]: 118), bahwa Allah tidak menjadikan manusia satu umat saja, (Q.S. Al-Hujurat [49]: 13) melainkan menakdirkan dalam keragaman suku, bangsa dan warna kulit, bahasa, agama dan keyakinan, bukan dalam keseragaman (Q.S. Ali Imran [3]: 64, dan Yunus [10]: 7) Perbedaan atau keragaman tersebut harus diterima sebagai sebuah kenyataan positif (Q.S. Ar-Rum [30]: 22) dan tidak boleh berprasangka serta saling mencerugai (Q.S. AlHujurat [49]: 15). Bahkan perbedaan tidak perlu digusarkan dalam hidup,

\footnotetext{
${ }^{11}$ Komarudin Hidayat \& Muhammad Wahyudin Nafis, Agama Masa Depan, Perspektif Filsafat Perinial, (Jakarta Paramadina, 1995), h. 71.

${ }^{12}$ Nurcholish Madjid, Dalam Kata Pengantar: Grose \& Hubbard, h. xix.
} 
hendaklah dipergunakan sebagai pangkal tolak berbuat kebajikan, dan menjadi kekuatan dalam menegakkan persatuan. Dengan demilian harus diakui bahwa kemajemukan merupakan sunnatullah, tetapi bagaimana mengatur sesuai proporsinya tanpa mengeliminasi dan mengingkari perbedaan-perbedaan yang ada dalam kenyataan masyarakat dan bangsa. Begitu indahnya pendidikan Islam sehingga Badri Khaeruman" mengatakan "Islam itu pembawa rahmat bagi sekaliaan alam bukan laknat". Semua orang harus mengupayakan kemajemukan yang ada tidak menimbulkan perpecahan (dis integrasi) yang menyebabkan pertikaian yang berkepanjangan. Begitu juga sebagaimana disampaikan Mulyasa ${ }^{14}$ bahwa kita harus menghargai keberagaman agama, budaya, ras, dan golongan sosial ekonomi dalam lingkungan sosial.

\section{Pembahasan}

Dalam mengimplementasi pendidikan Islam berwawasan multikultural di IAIN Kerinci, berdasarkan hasil wawancara dengan ketua Jurusan Bimbingan Konseling Pendidikan Islam diperoleh informasi, bahwa terlebih dahulu dosen harus membuat Rencana Pelaksanaan Pembelajaran (RPP) atau biasa disebut dengan Satuan Acara Perkuliahan (SAP), karena SAP memiliki peranan penting dalam menentukan berhasil tidaknya suatu pendidikan, karena "no plan, no future", tanpa perencanaan tidak ada masa depan, begitu juga urgennya rencana dalam sebuah perkuliahan. Maka dosen mata kuliah multikultural wajib menyusun SAP secara lengkap dan sistematis terhadap mata kuliah yang diasuh sesuai dengan profesinya, agar perkuliahan dapat berlangsung secara interaktif, inspiratif, efektif, kreatif, inovatif, dan menyenangkan.

Selanjutnya peneliti juga melakukan wawancara mendalam dengan dosen pengampu mata kuliah, maka diperoleh informasi bahwa beliau memang telah membuat SAP sesuai dengan materi, topik inti atau tema yang terdapat dalam kurikulum, peneliti juga melakukan observasi terhadap proses perkuliahan, melihat secara nyata bagaimana internalisasi dan implementasi di lokal. Di

\footnotetext{
${ }^{13}$ Badri Khaeruman, Moralitas Islam, (Bandung: Pustaka Setia, 2004), h. 204.

${ }^{14}$ E. Mulyasa, Manajemen Pendidikan Karakter, (Jakarta: Bumi Aksara, 2014), h.11
} 
samping itu juga menganalisis terhadap perencanaan perkuliahan sebagaimana tertera dalam Satuan Acara Perkuliahan (SAP). Adapun SAP yang mengacu pada komponen Kerangka Kualifikasi Nasional Indonesia (KKNI) adalah:

1. Identitas Satuan Pendidikan Jurusan Bimbingan Konseling Pendidikan Islam (BKPI) pada Institut Agama Islam Negeri (IAIN) Kerinci.

2. Identitas mata kuliah atau tema/subtema

Nama mata kuliah: Pendidikan Multikultural

Kode mata kuliah $\quad$ : BKPI 27

Tema/subtema $\quad$ : Multikultural, Kedamaian dalam Keragaman

3. Kelas/Semester

Kelompok mahasiswa yang mengikuti perkuliahan adalah semester Genap (VI) kelas A, B, C, D. Tahun 2018.

4. Materi Pokok

Materi pokok/tema pokok yang akan dikaji dan didiskusikan dalam kegiatan perkuliahan adalah tentang: Keragaman Budaya: Keragaman Syariat (Q.S. Al-Hajj [227]: 67. Beberapa umat (Q.S. Al-An 'Am [6]: 42. Beberapa kaum (Q.S. Hud [11]:118. Beberapa suku (Q.S. Al-Hujurat[49]: 13. Menghargai perbedaan (Q.S. Fush Shilat [41]: 33). Berlomba membuat kebajikan (Q.S. Al Maidah [5]: 48). Kedamaian: Sebagai salah satu nama Tuhan (Q.S Al Hasyr [59]:23 dan nama surga (Q. S Al Fajr [89]: 30. Islam cinta serta condong pada kedamaian: (Q.S. Al-Baqarah [2]: 205. Lukman [31]:11. AnNisa' [4]: 114. Al-Hujurat [49]: 9-10. Al-An'am [6]: 127. Al Anfal [8]: 61-62. Al-Furqan [25]: 63.

5. Alokasi Waktu

Alokasi waktu dihitung dalam menit yaitu selama 150 menit, dengan rincian Pendahuluan 10 menit, kegiatan inti 130 menit, dan penutup 10 menit.

6. Tujuan perkuliahan/pembelajaran

a. Menjelaskan konsep/prinsip serta manfaat tentang multikultural, menciptakan kedamaian dalam keragaman atau keanekaragaman. 
b. Mahasiswa dapat mensikapi serta menerima tentang keragaman budaya, pentingnya membangun kedamaian dalam keragaman budaya tersebut.

c. Mahasiswa terampil dalam mempraktikkan sikap keselarasan, keserasian, kecocokan, kesesuaian dan kerukunan atau menciptakan kondisi yang aman dan damai.

d. Kompetensi/Capaian pembelajaran dan indikator pencapaian kompetensi

e. Mahasiswa dapat memahami konsep/prinsip perbedaan, keanekaragaman, keragaman budaya serta menghargai, menghormati keragaman tersebut sebagai rahmatan lil alamin, khazanah dan kekuatan dalam membangun persatuan dan kesatuan bangsa, dalam bingkai "Bhinneka Tunggal Ika"

f. Mahasiswa membiasakan diri dalam kedamaian, keselarasan, keserasian, kecocokan, kesesuaian dan kerukunan dalam keragaman.

g. Mahasiswa dapat menampilkan, melaksanakan, menerapkan serta menyukai kedamaian, bebas dari konflik, perselisihan, pertentangan, serta gangguan, suka akan ketenangan dan menerima perbedaan.

7. Materi Perkuliahan/Pembelajaran

Konsep/prinsip serta manfaat tentang:

a. Keragaman Budaya: Keragaman Agama: Islam, Katholik, Protestan, Hindu, Budha, Kongkoncu. Keragaman Budaya: Suku Jambi, Palembang, Batak, Aceh, Minang, Jawa, Bugis dan lain-lain.

b. Harmoni : Menghargai, menghormati keberagaman agama dan budaya, suku dan etnis dalam lingkungan sekitar, nasionaal dan global. 
c. Kedamaian: Menyukai adanya harmoni dan bebas dari konflik, perselisihan, pertentangan dan gangguan, serta suka akan ketenangan, keamanan.

8. Pendekatan dan Metode Perkuliahan/Pembelajaran

Pendekatan yang digunakan adalah adalah student center learning (SCL) atau student active learning (SAL), pendekatan yang berpusat pada mahasiswa, untuk mewujudkan suasana belajar dan proses pembelajaran dapat berjalan secara interaktif, inspiratif, menantang, efesien, efektif, kreatif, inovatif dan menyenangkan. Pendekatan ini dilakukan karena memerhatikan keragaman, budaya dan etnis mahasiswa. Di samping itu juga dilakukan dengan pendekatan dialogis untuk menanamkan kesadaran hidup bersama dalam keragaman dan perbedaan. Lebih mengggunakan pendekatan mengajarkan tentang agama (teaching about religion) yang menggunakan pendekatan kesejarahan dan perbandingan, sehingga mahasiswa bisa aktif mencari, menemukan dan mengevaluasi pandangan dalam berbagai agama dan budaya, dengan demikian tumbuh sikap damai.

Metode yang digunakan adalah metode small group discussion dengan cara membagi kelompok, lalu dilakukan dialog diskriptif, dialog naratif dan dialog argumentatif. Antar kelompok mendiskusikan ayat AlQur'an dan Hadis Nabi yang berhubungan dengan pendidikan Islam bermuatan multikultural, dan peran kedamaian dalam kemajemukan Di samping itu juga menerapkan metode keteladanan, metode mengajar beregu (team teacher) dilakukan tanpa membedakan latar belakang mahasiswa.

9. Media Perkuliahan/Pembelajaran
a. Lap Top, in fokus
b. Buku tulis, kertas plano
c. Slide, vidio, film

10. Sumber Belajar
a. Al-Qur'an dan Hadits
b. Kitab-kitab, multikultural, kedamaian dalam keragaman budaya, media cetak yang relevan
c. Sumber elektronik 
11. Langkah-langkah Perkuliahan

a. Kegiatan Pendahuluan

- Eksplorasi

Berdo'a dengan esensi syukur atas nikmat kesehatan dan minta dibukakan hati dan diberi cahaya hikmah agar mudah menerima pembelajaran hari ini. Menanyakan kabar mahasiswa serta mengecek kehadiran mahasiswa.

- Apersepsi

Tahap ini adalah proses pengosongan atau pengalihan pikiran mahasiswa, dengan melakukan beberapa taktik untuk menarik perhatiannya, dalam bentuk memberi teka teki, anekdot, atau cerita yang up to date, seperti berita atau isu-isu terkini. Dosen menceritakan tentang pengalamannya pergi ke Jambi, di sana ditemukan banyak komunitas yang berbeda baik dari segi keragaman agama, maupun suku, seperti suku Aceh, Minang, Batak, Palembang, Jawa, Banjar, Cina, Teonghoa, dan lainnya.. Kendatipun berbeda-beda, namun mereka terlihat sangat harmonis, toleransi, peduli, hidup dengan aman dan damai. Dosen dapat bertanya tentang daerah-daerah yang pernah dikunjungi oleh mahasiswa.

Setelah pengalihan pikiran mahasiswa terhadap dosen, kemudian dialihkan perhatiannya ke materi perkuliahan dengan cara melakukan tahap asosiasi.

- $\quad$ Asosiasi

Asosiasi di sini diartikan sebagai pembentukan hubungan atau pertalian antara gagasan, ingatan, atau kegiatan pancaindra. Dosen menghubungkan materi perkuliahan dengan sebuah cerita imajiner atau faktual. Dalam materi perkuliahan keragaman atau keanekaragaman budaya, dan kedamaian, dengan subtema damai dalam keragaman budaya, dosen menceritakan kisah atau peristiwa tentang kedamaian tersebut.

- Motivasi

Dengan mengemukakan cerita yang berkaitan dengan keragaman budaya, dan kedamaian, maka mahasiswa termotivasi untuk selalu 
menciptakan kedamaian dalam kehidupan sosial tanpa membedakan suku, bertoleransi karena perbedaan adalah untuk saling melengkapi, saling menguat, bukan untuk saling membenci, agar tercipta kedamaian dalam lingkungan sekitar, nasional maupun global.

b. Kegiatan Inti

- $\quad$ Elaborasi

Dosen melakukan presentasi singkat tentang keragaman budaya, dan kedamaian.

Dosen menggunakan pendekatan student center learning (SCL) atau student active learning (SAL), kegiatan yang berpusat pada mahasiswa, lalu direalisasi dengan menggunakan metode small group discussion dengan cara:

Dosen membagi mahasiswa kepada 3 kelompok untuk dapat melakukan dialog/diskusi di antara mereka: 1 kelompok mendiskusikan tentang filosofi pendidikan Islam multikultural, 1 kelompok mendiskusikan tentang keragaman masyarakat, dan 1 kelompok menerangkan tentang kedamaian, harmoni dalam keragaman.

Sekretaris mencatat hasil diskusi di dalam kertas plano atau buku tulis, terutama point-point penting.

Wakil kelompok mempresentasikan hasil diskusi di dalam kelas dihadapan kelompok-kelompok yang lain. Mereka berkomitmen menerima perbedaan untuk saling berdampingan dalam kemajemukan budaya, dan mencipta kedamaian.

- $\quad$ Konfirmasi

Dosen menjelaskan materi yang telah dipresentasi oleh mahasiswa dengan menambahkan beberapa point berdasarkan ayat-ayat lainnya tentang perbedaan bahasa dan warna kulit (Q.S. Ar Rum [30]: 22, Anjuran berkata lemah lembut qawlan layyinan (Q.S. Thaha [20]: 44, menyenangkan qawlan ma'rufan (Q.S. an Nisa'[4]: 8. 
Melarang mengucapkan berita yang bersifat sensasi (Q.S. An Nur [24]: 14-16.

c. Kegiatan Penutup

Dosen bersama-sama dengan mahasiswa menyimpulkan esensi perkuliahan.

- Refleksi

Dosen bersama mahasiswa mengungkapkan kesan mengenai pentingnya memahami, menyikapi serta mengamalkan sikap kedamaian dalam kehidupan sehari-hari baik dalam lingkungan sekitar, nasional maupun global.

Dosen menginformasikan kepada mahasiswa tentang bahan pertemuan berikutnya adalah tentang kebersamaan, saling mencintai dan moderasi.

Do'a penutup dengan esensi agar diberi berkah berupa tersimpannya ilmu dalam pikiran serta ucapan syukur atas terselenggaranya perkuliahan pada hari ini dengan baik.

12. Penilaian Hasil Perkuliahan/Pembelajaran.

Pada tahap ini dosen melakukan penilaian terhadap proses dan hasil perkuliahan dalam kurun waktu satu semester, baik dalam bentuk formative test untuk memberi feed back pada dosen atas jawaban mahasiswa, maupun sumative test sebagai tes formal. Di samping itu juga menggunakan teknik penilaian nontes dalam bentuk penilaian diri untuk mengukur ranah sikap, pengetahuan dan keterampilan yang dimiliki mahasiswa. Penilaian juga dilakukan secara komprehensif yang memenuhi aspek intelektual, moral, emosional, dan spiritual.

Keberhasilan perkuliahan diukur dari hasil empat pilar pengalaman belajar yaitu: 
Selain memiliki kemampuan dalam bidang wawasan kognitif dan pengetahuan (learning to know); mahasiswa juga harus memiliki kemampuan mempraktikkan pengetahuan (learning to do); memiliki kepribadian dalam pola pikir dan tingkah lakunya (learning to be); dan dapat diamalkan dalam kehidupan bersama (learning to life to gether). Dengan implementasi pendidikan Islam berwawasan multikultural, mahasiswa dapat menyebarkan ke tengah masyarakat bahkan menjadi pelopor, garda terdepan dalam menciptakan kedamaian dan harmoni dalam masyarakat yang majemuk sehingga bisa bebas dari konflik.

\section{Pembahasan}

Berdasarkan hasil temuan di atas maka dapat di pahami secara lebih dalam lagi bahwa pendidikan multikultural lebih ditekankan pada kesiapan menerima pluralisme budaya dan bersikap toleran dan inklusif. Dengan kata lain pendidikan multikulturalisme mempunyai tujuan untuk membentuk "manusia budaya" dan menciptakan "masyarakat manusia berbudaya" dalam masyarakat yang plural. Di samping itu juga akan memiliki sikap toleransi terhadap perbedaan individu yang berbeda kultural, fisik (warna kulit, ketampanan, dan lainnya) maupun psikis (hobi, kemampuan intelektual, bakat, dan minat). Melalui pendidikan multikultural mahasiswa tersebut di samping berilmu dan terampil, juga dapat hidup bersama di tengah masyarakat dalam lingkungan keluarga, regional, nasional dan bahkan internasional. Dengan demikian pendidikan multikultural ini mampu membangun kebersamaan dalam keragaman sekaligus dapat meredakan ketegangan sosial yang diakibatkan oleh latar belakang yang berbeda.

Jurusan Bimbingan Konseling Pendidikan Islam (BKPI) IAIN Kerinci bersama dengan para dosen yang mengasuh mata kuliah pendidikan multikultural yang berwawasan pendidikan Islam, hendaknya menyiapkan topiktopik seperti : Mengandung aspek pengurangan prasangka (prejudice reduction) terhadap perbedaan ras atau etnik dan kelompok budaya lain. Mengembangkan perilaku inter-group yang lebih positif, penyediaan kondisi yang mapan dan pasti. Mengandung dimensi pendidikan yang sama/adil (equitable pedagoqy). Memberikan pengalaman pendidikan persamaan hak dan persamaan 
memperoleh kesempatan untuk mendapat pendidikan, serta tidak diskriminatif terhadap banyak jenis kelompok yang beragam etnik, gender dan lainnya. Mengandung dimensi pemberdayaan budaya kampus dan struktur sosial (empowering school culture and social structure). Memperdayakan budaya mahasiswa dari kelompok yang beraneka ragam, untuk menyusun struktur sosial kampus sehingga menjadi karakteristik dan terbentuknya budaya kampus.

Di samping itu yang paling penting dampak positif dari implementasi pendidikan multikultural adalah lahirnya kondisi yang damai di tengah masyarakat, karena ucapan assalamu'alaikum (kedamaian bagi kalian semua). Kata salam (damai) sebagai salah satu nama Tuhan (Q.S.Al-Hasyr [59]: 23). Mereka yang menginginkan ridha Tuhan hendaknya mengikuti “jalan damai”(Q.S. AnNahl [16]: 5). Surga yang diidamkan oleh semua orang juga disebut dengan nama "rumah kedamaian (dar al-Salam)" (Q.S.Al-Fajr [89]: 30). Allah mengucapkan salam perdamaian, sebagai ucapan selamat dari Tuhan Yang Maha Penyayang (Q.S.Yaa siin [36]: 56). Inti kedamaian yakni kesadaran bahwa setiap amalan yang bersifat vertikal (bablum minallah) seharusnya diimplikasi pada tegaknya nilai-nilai horizontal-kemanusiaan (bablum minannas), agar terhindar dari kehinaan (Q.S. Ali Imran [3]: 112).

Bahkan bukan saja sekadar damai, namun di antara mereka tumbuh kasih sayang, yaitu perlakuan lemah lembut terhadap orang lain, belas kasih terhadap mereka dan upaya menghapus air mata kesedihan dan penderitaan. Rasulullah Saw. telah menjadikan kasih sayang manusia sesama mereka sebagai jalan untuk mendapatkan kasih sayang Allah kepada mereka. Bahkan lebih lanjut dikatakan bahwa kasih sayang orang mukmin itu tidak terbatas pada saudara sesama mukmin saja, bahkan melimpah untuk seluruh umat manusia, sekalian alam (rahmatan lil alamin) yakni Islam yang berwajah damai, manusiawi. Nabi bersabda, "Kasih sayang itu bukanlah kasih sayang seseorang di antara kamu kepada sahabatnya (yang mukmin) saja, tetapi kasih sayang yang menyelurub(Kepada selurub umat manusia)". Artinya kaum muslimin harus rela menerima kehadiran nonmuslim sebagai saudara sebangsa. 
Dalam perjalanan sejarah ada yang patut dijadikan teladan bagi umat manusia yang mana persaudaraan yang lebih mengutamakan orang lain (antara kaum Anshar dengan Muhajirin), sehingga terjalin saling kasih mengasihi, dan sayang menyayangi di antara mereka. (Q.S. Al-Hasyr [59]: 9) "Dan mereka (Anshar) tiada menarub keinginan di dalam bati mereka terbadap apa-apa yang diberikan kepada mereka (orang Mubajirin); dan mereka mengutamakan (orang Mubajirin) atas mereka sendiri, kekalipun mereka dalam kesusahan". Jalinan kasih sayang sosial yang ditunjukkan oleh kaum Anshar ini, tidak ada bandingnya di dalam sejarah umat manusia. Bahkan Allah akan mengangkat derajat seseorang apabila ia mampu berlemah lembut terdapat orang yang jahil terhadap dirinya, dan memaaf terhadap orang yang berbuat zalim pada dirinya. Itulah pendidikan Islam tentang kelemah lembutan, kasih sayang sosial yang harus diberikan kepada anak-anak mereka, agar anak-anak bisa tumbuh dan berkembang menjadi generasi yang sopan santun, hormat, serta konsisten. Bahkan secara lebih luas Rasulullah bersabda: "Sesungguhnya Allah menyukai kelemah lembutan di dalam selurub perkara". (H.R. Al-Bukhari).

Dalam hal berkomunikasi atau berinteraksi baik antara muslim maupun dengan non muslim, kita hendaknya dapat memelihara karakter muslim agar menjadi muslim yang simpatik, hendaknya tidak menjadi kompor pemanas yang dapat mengakibatkan pertentangan, tapi harus menjadi penyejuk yang dapat menebarkan kedamaian dan kemaslahatan bersama sesama umat manusia. Sesuai dengan misi ajaran Islam sebagai penyebar kedamaian dan kemaslahatan. Konsep Pendidikan Islam dalam berinteraksi sosial lebih berorientasi pada pencapaian "kedamaian" dan " kerukunan" antara sesama manusia, tanpa melihat latar belakang agama atau ras. Dalam berkomunikasi banyak sekali ditemua ayat yang menganjurkan supaya mengeluarkan kata-kata: (qawlan sadidan=kata yang benar (Q.S. An-Nisa' [3]: 9, qawlan layyinan=lemah lembut (Q.S. Taha [20]: 44), qawlan kariman=mulia (Q.S. Al-Isra' [17]: 23), qawlan ma'rufan=menyenangkan (Q.S. An-Nisa' [4]: 8), qawlan balighan=membekas pada jiwa (Q.S. An.Nisa' [4]: 63), qawlan maysuran=lemah lembut (Q.S. Al- Isra' [17]: 28).

Sebaliknya Allah tidak menyukai kerusakan (fasad) kekerasan, kebrutalan, konflik, yaitu tindakan yang mengakibatkan gangguan tatanan sosial, menyebabkan hilangnya nyawa dan harta (Q.S. Al-Baqarah [2]: 205). Bahkan 
Islam melarang memunculkan ucapan atau berita yang bersifat sensasi (Q.S. AnNur [24]: 14-16\} dapat dikategori sebagai berita sensasional dapat menciptakan kerusuhan, konstruktif atau destruktif. Begitu juga pada firman Allah yang lain "Sesunggubnya syaitan itu menimbulkan perselisiban di antara mereka" (Q.S. AlIsraa'[17]: 53). Pengertian nazagha adalah menebar permusuhan, merusak dan memotivasi untuk berbuat jahat. Nazagha baynana berarti 'afsada, merusak, menghasut untuk berbuat jahat.

Jika masyarakat sudah dapat menciptakan kedamaian serta berkasih sayang, maka apa yang kita takuti selama ini seperti terjadinya konflik di manamana, tidak akan terjadi lagi. Ini akan menjadi senjata yang ampuh untuk mengantisipasi konflik serta menjadi harapan dalam mencipta perdamaian dunia. Apalagi Indonesia telah menjadi rujukan dunia dalam bidang kedamaian, toleransi, moderat, bahkan Indonesia bisa jadi pusat peradaban Islam dunia. Selanjutnya pendidikan Islam multikultural merupakan kontribusi yang sangat fondamental dalam menangkal radikalisme, merupakan ajaran moderat, damai, toleransi, inklusif, tanpa kekerasan.

Dalam menghadapi masyarakat yang multikultural, maka sudah saatnya kita mempersiapkan generasi muda yang mencintai kedamaian, memiliki wawasan kebangsaan yang luas, terutama melalui lembaga pendidikan, diharapkan akan terbangun generasi yang memiliki karakter cinta damai, menuju Indonesia yang berintegritas, beretos kerja, dan gotong royong di atas prinsip kebersamaan sebagai tradisi dan khas bangsa, menjadi Indonesia yang hebat dan bermartabat, yang dapat menjamin kelangsungan hidup bangsa dan negara, dapat mempertahankan Pancasila dan keutuhan NKRI.

\section{Kesimpulan}

Indonesia secara umum terkenal sebagai negara multikultural yang memiliki keragaman budaya, begitu juga khususnya Kerinci. Kondisi inilah yang membuat terjadinya konflik. Dalam menghadapi ini diperlukan pendidikan Islam yang berwawasan multikultural. Karena Allah memang telah menciptakan 
manusia dengan keragaman, bukan keseragaman. Keragaman agama, umat, kaum, suku, bangsa dan budaya merupakan rahmat, sunnatullah, berkah, kekayaan, keharusan. Keragaman merupakan konsekwensi logis dari keadilan Ilabi, yang tak perlu digusarkan, tapi harus dikelola, kita tidak boleh cendrung melihat banyak perbedaan, tapi lihatlah banyak persamaan dan dapat berbagi keragaman.

Sikap damai dan harmoni dalam masyarakat multikultural sangat besar, dan dalam keragaman budaya kita tidak boleh ekstrim, melakukan konflik, berprasangka buruk, tetapi hendaknya dapat membangun kedamaian, suka akan ketenangan kasih sayang, berlemah lembut, saling menghargai, mengasihi, menghormati, tenggang rasa, simpati, saling menerima, mencintai pertemanan. Dapat membangun kebersamaan, saling berdampingan, dapat menciptakan kesejukan dan kenyamanan.

Dosen Pendidikan multikultural di IAIN Kerinci telah membuat Rencana Satuan Acara Perkuliahan (SAP), serta telah mengimplementasikan dalam proses pembelajaran. Proses pembelajaran dapat berlangsung dengan efektif, efesien dan menyenangkan. Dengan penerapan materi damai dalam kemajemukan, telah menunjukkan hasil yang positif, para mahasiswa memberi respons, dan telah mampu memberi solusi, melakukan, mengembangkan, serta mengamalkan sikap inklusif, menerima keragaman budaya sebagai realita kehidupan, serta dapat menciptakan kedamaian dalam keragaman budaya dalam kehidupan sekitar, nasional dan global. 


\section{Bebliografi}

Departemen Agama RI., Al-Qur'an dan Terjemahnya,(Jakarta: Yayasan

Penyelenggara Penterjemah/Pentafsir Al-Qur'an Departemen Agama RI, 1983)

Abd. Rahman Assegaf, Filsafat Pendidikan Islam, Paradigma Baru Pendidikan

Hadhari Berbasis Integratif-Interkonatif, (Jakarta: Raja Grafindo Persada, 2011)

Ali Maksum dan Luluk Yunan Ruhendi, Paradigma Pendidikan Universal di Era

Modern dan Post-Modern (Mencari "Visi Baru" atas Realitas Baru" Pendidikan Kita,(Jakarta: IRCIoD, 2004)

Amir Rusdi,"Perspektif Islam tentang Keberagaman dan Penyikapannya dalam

Konteks Pengembangan Kurikulum PAI" dalam Consiencia, Vol. 1, No. 2, 2007

Azyumardi Azra, Pendidikan Agama Multikultural, (Jakarta: UIN Syarif

Hidayatullah, 2004)

--------, Merawat Kemajemukan Merawat Indonesia, (Yokyakarta: Institute

Pluralism and Multikulturalism Studies (Impulse) dan Kanisius, 2007)

Badri Khaeruman, Moralitas Islam, (Bandung: Pustaka Setia,2004)

Budhy Munawar Rachman, Islam Pluralis, Wacana Kesetaraan Kaum Beriman

Paramadina,(Jakarta: Paramadina, 1995)

Dede Rosyada, "Pendidikan Multikultural Melalui Pendidikan Agama Islam"

dalam DidaktikaIslamika Jurnal Kependidikan Keislaman dan Kebudayaan, Vol.VI No. 1, Januari 2013

H.A.R. Tilaar, Multikulturalisme Tantangan-Tantangan Global Masa Depan 
124 | BELAJEA : Jurnal Pendidikan Islam, Vol. 3, No. 02, 2018

dalam Transformasi Pendidikan Nasional, (Jakarta: Grasindo, 2004)

Imam Tholhkhah dan Ahmad Barizi, Membuka Jendela Pendidikan mengurai

Akal Tradisi dan Integrasi Keislaman Pendidikan Islam,(Jakarta: Raja Grafindo Persada,2004)

Komaruddin Hidayat \& Muhammad Wahyudin Nafis, Agama Masa Depan,

Perspektif Filsafat Firinial,( Jakarta: Paramadina, 1995)

Mastuki, Kualitas Lulusan Perguruan Tinggi dan Akseptabilitas stakeholder

(Pemikiran untuk Perombakan Kurikulum di PTAI), Makalah pada Seminar Reorientasi Kurikulum dan Kerjasama STAIN Kerinci, 8 Januari 2014

Muchlas Samani dan Hariyanto, Konsep dan Model Pendidikan Karakter (Bandung: Remaja Rosdakarya, 2013

Nurcholis Madjid, "Islamic Roots Of Modern Pluralis: Indonesian Experiences"

dalam Jurnal Studia Islamika, (Jakarta: IAIN Syarif Hidayatullah, 1994)

Suyadi, Strategi Pembelajaran Pendidikan Karakter, (Bandung: Remaja Rosdakarya, 2013 